\title{
ISLAM FOBI DAN AKSI-AKSI RADIKAL
}

\author{
Mohammad Iskandar
}

\begin{abstract}
During the Dutch colonial government, social protests under the leadership of some Islamic ulamas were suppressed ruthlessly. In 1710, during the time of the East India Company (VOC), some farmers from Jampang, Sukabumi led by two ulamas rebelled against the Company. Even after the Diponegoro war in Java in 1883, in 1885-1888 there were farmers fighting against the colonial government in Ciomas, Banten and the war was named a holy war, fi sabililah war, and so were in 1904 in Aceh and in 1919 in Cimareme, Garut. Since Islamophobia became a modern phenomenon, and it did not only happen in recent occurrence of the post World Trade Center tragedy, it has been taken place even in the past. The general colonial policy was cautious against Islam and it barred the growth of pesantren, or the religious schools, and marginalized them for its anti-modernist stand. Indonesia, the United States, the United Kingdom, and Australia indirectly labeled Islam as terrorists.
\end{abstract}

\section{Keywords}

Islamophobia, ulama, fanaticism, sectarian, tarekat.

Ajengan-ajengan cing sing boga kekenyos, ulah datang ka elat, sumawona lamun mundur, era ku batur jeung moal aya kasukaan, sorban bae gedekeun.

Kangrama di Cipari

Haji Mugni ${ }^{1}$

Kalimat di atas merupakan kutipan dari surat Haji Mugni, salah seorang ulama Sunda asal Cipari, Garut-Indonesia, yang ditujukan kepada para kiai (ajengan). Isi surat itu tiada lain adalah ajakan atau seruan kepada mereka agar mereka tidak tenggelam dalam membesar-besarkan simbol keulamaan, tetapi cepat bergerak memajukan dan meneruskan perjuangan. Menurut pemerintah kolonial Hindia Belanda, surat itu

\footnotetext{
${ }^{1}$ Inventaris R.A. Kern No. 343, Koningklijk Instituut voor Taal-, Land- en Volkenkunde (KITLV), Leiden, Netherland.
} 
ditemukan dari salah satu rumah yang diduga terlibat dalam peristiwa yang terjadi pada 17 Juli 1919 di Cimareme, kabupaten Garut. ${ }^{2}$

Peristiwa itu bermula dari penolakan Haji Muhammad Hasan Arif-yang lebih dikenal dengan sebutan Haji Hasan terhadap tuntutan pemerintah yang mewajibkan menjual hasil panen padinya sebanyak 42 pikul dengan harga f.5 per pikul. Haji Hasan mengatakan hanya bersedia menjual padinya sebanyak 10 pikul saja. ${ }^{3}$ Alasannya karena hasil panennya tidak cukup untuk membiayai hidup keluarganya. Apalagi sebelumnya, pihak pemerintah juga telah merugikannya dengan cara memaksa mengubah kebun jeruknya menjadi lahan sawah. Padahal secara ekonomis, hasil produksi kebun jeruk jauh lebih menguntungkan dibandingkan dengan sawahnya. Semua alasan keberatannya telah dituliskan dalam surat yang dikirimkannya kepada pemerintah setempat.

Akan tetapi, pemerintah setempat tidak dapat menerima keberatan yang diajukan Haji Hassan. Pemerintah tetap pada keputusannya dan mengancam akan menindak secara tegas jika dia tetap membangkang. Ancaman itu akhirnya dibuktikan manakala Haji Hasan tetap pada pendiriannya. Pemerintah mengirimkan pasukan bersenjata untuk menangkap Haji Hasan, yang dipimpin langsung oleh Bupati Garut yang didampingi Asisten Residen Garut.

Meskipun rumahnya telah dikepung, Haji Hasan tidak mau memenuhi seruan untuk menyerah. Ia beserta sanak keluarga dan pengikutnya memilih untuk tetap bertahan di dalam rumahnya. Tindakannya itu, akhirnya membuat Bupati dan Asisten Residen Garut hilang kesabaran, sehingga memerintahkan pasukan bersenjata yang dibawanya untuk segera menembaki rumah tersebut. Selesai melakukan penembakan, komandan pasukan memerintahkan anak buahnya untuk melakukan penggeledahan ke dalam rumah. Mereka menemukan hampir semua "penghuni rumah", temasuk Haji Hassan.

Penggeledahan juga dilakukan terhadap rumah-rumah di sekitar tempat kejadian, yang kemudian diikuti oleh operasi penangkapan terhadap orang-orang tertentu, yang berlanjut sampai beberapa hari berikutnya. Satu hal yang menarik dari kejadian itu adalah pernyataan resmi pemerintah tentang dalang peristiwa itu. Menurut pihak pemerintah, pembangkangan keluarga Haji Hasan didalangi oleh sekelompok orang Islam radikal yang tergabung organisasi yang bernama Sarekat Islam (SI) afdeling-B. Organisasi ini merupakan bagian tidak terpisahkan dari Sarekat Islam, yang sifatnya rahasia dengan tujuan untuk melakukan pemberontakan terhadap pemerintah Hindia Belanda.

Tidak aneh jika pernyataan itu menuai protes dari pucuk pimpinan Central Sarekat Islam(CSI), Haji Cokroaminoto. Sebab, bukan saja karena pernyataan itu terlalu dini karena

\footnotetext{
2 Sartono Kartodirdjo. Ratu Adil. Jakarta: Sinar Harapan. 1984, 76-77.

${ }^{3}$ Else Ensering. "De ontdekking van de Afdeeling B van de Sarekat Islam al seen case study in de locale geschiedenis van de Preanger Regentschappen" (Skripsi doctoral Universitas Amsterdam, Amsterdam, 1982), 16 .
} 
proses pengadilan pun belum berjalan; tetapi juga karena tuduhan itu terkesan ingin mengalihkan perhatian dari isu pokok ke isu lain. Tepatnya, dari masalah pangan (beras) kepada isu lain yang berbau politik, yaitu pemberontakan dengan mengkabinghitamkan kelompok Muslim (yaitu SI afdeling-B). ${ }^{4}$

Tulisan di bawah ini mengungkapkan kembali, apa sebenarnya yang membuat pemerintah kolonial Belanda (Hindia Belanda) sangat curiga kepada kaum Islam (Islam fobi). Hal ini cukup penting diungkapkan, mengingat sikap Islam fobi itu ternyata tetap berkembang sampai masa kini. Contoh mutakhir yang paling jelas menyangkut Islam fobi adalah peristiwa 11 September 2001 di New York, yaitu ditabraknya gedung kembar World Center. Meskipun Presiden George W. Bush tidak menyatakan bahwa yang meruntuhkan gedung kembar itu kaum Islam, namun dalam tindakannya untuk mencari "teroris internasional" penyebab peristiwa itu selalu mengarah ke Islam. Bahkan secara jelas dia mengatakan bahwa perang melawan teroris itu sebagai Perang Salib. Walaupun demikian tulisan ini tidak akan membahas masalah kontemporer karena fokus tulisan terarah pada peristiwa yang terjadi pada kurun waktu akhir abad ke-19 sampai awal abad ke-20.

\section{IDE-IDE KEAGAMAAN DALAM AKSI-AKSI KOLEKTIF}

Dalam lembaran sejarah Indonesia, aksi-aksi kolektif, baik yang disebut sebagai "kerusuhan", "protes", "perlawanan", "makar", atau "pemberontakan", yang di dalamnya terkait isu-isu dan simbol-simbol keagamaan, dapat dikatakan relatif cukup banyak, terutama pada periode kolonial Belanda. Seperti telah disinggung di atas, dalam peristiwa Cimareme, muncul kasus SI Afdeling-B sebagai unsur Islam yang dituduh merencanakan pemberontakan. Kecurigaan pemerintah kolonial Belanda terhadap SI sebenarnya sudah ada sejak para pendiri organisasi itu meminta pengakuan hukum dari pemerintah. Bahkan kalau ditarik lagi jauh ke belakang ke masa kekuasaan Vereenigde Oost Indische Compagnie (VOC) atau Kompeni, banyak aksi kolektif petani atau aksi menuntut perbaikan kesejahteraan yang dikategorikan oleh pemerintah sebagai kerusuhan melawan pemerintahan yang sah, Kompeni. Pada tahun 1710 misalnya, dilaporkan bahwa di daerah Jampang, Sukabumi, petani setempat telah melakukan perlawanan terhadap ketentuan-ketentuan Kompeni yang membebani kehidupan mereka. Perlawanan itu dipimpin oleh seorang ulama dengan melibatkan sekitar 1000 orang petani. ${ }^{5}$ Tiga tahun kemudian, di tempat yang hampir sama kembali muncul aksi kolektif menentang para bupati Kompeni. Pemimpin aksi itu yang mengaku bernama

\footnotetext{
${ }_{4}$ Karen Armstrong. Perang Suci: Dari Perang Salib Hingga Perang Teluk. Terjemahan oleh: Hikmat Darmawan. Jakarta: Serambi. 2001.

${ }^{5}$ Dr. F. de Haan. Priangan: De Preanger-Rengentschappen onder het Nederlandsch Bestuur tot 1811. Bataviaasch Genootschap van Kunsten en Wetenschappen. 1911, 470.
} 
Dermakusuma yang mendapat dukungan dua orang ulama bernama Tanuputra dan Wiradana berjanji akan membunuh bupati Cianjur, Ciblagung, Cikalong, dan Cileungsir. Namun sebelum kelompok Dermakusuma berbuat banyak, pasukan Kompeni berhasil mendesak dan mengusir kelompok itu keluar wilayah Sukabumi. ${ }^{6}$

Setelah kekuasaan Kompeni pindah ke tangan pemerintah Hindia Belanda sikap Islam fobi tidak banyak mengalami perubahan, walaupun pemerintah (melalui undangundangnya) menyatakan netral agama. Penyebabnya tiada lain karena banyaknya perlawanan petani atau rakyat, terutama pada paruh akhir abad ke-19, yang dinilainya diilhami oleh ideologi Islam. Sebut saja misalnya, aksi kolektif petani Patik, Madiun bulan November 1885, aksi kolektif petani Ciomas pada bulan Februari dan Mei tahun 1886, aksi kolektif petani Banten tahun 1888 (Pemberontakan petani Banten), peristiwa Gedangan tahun 1904, dan peristiwa Pak Jebrak tahun 1919.7 Banyak pejabat pemerintah kolonial Belanda waktu itu yakin semua pemberontakan itu mempunyai kaitan erat dengan ajaran Islam, seperti tercermin dalam beberapa laporannya. Padahal proses verbal yang dilampirkan dalam laporan-laporan itu terungkap cukup jelas bahwa orang-orang pribumi yang didakwa sebagai pelaku atau saksi, umumnya menyebut beban ekonomilah yang mendorong mereka melakukan aksi kolektif yang cukup radikal, dalam arti disertai tindak kekerasan. ${ }^{8}$

Dalam aksi perlawanan petani di Desa Patik, yang menjadi isu adalah tingginya tuntutan pajak. Orang swasta Belanda yang umumnya adalah pengusaha mengerti bahwa sebenarnya merekalah yang menjadi sasaran aksi itu. Apalagi setelah mereka mengetahui bahwa golongan priyayi tidak dijadikan sasaran. Oleh karena itu mereka menuduh mantan bupati Ponorogo yang disebut Bupati Tua sebagai biang keladinya. Alasannya, pertama, karena bupati itu bersikap anti-Belanda dan merupakan orang Islam yang sangat fanatik. Kedua, ia adalah anak kiai Imam Basari II, kepala desa perdikan dan pesantren Tegalsari dan Karanggebang. Padahal, para penyidik pemerintah sebenarnya telah menemukan bukti yang mengungkapkan bahwa isu pajak itu benar adanya. Namun mereka tidak mau mengakuinya. Jika benar aksi perlawanan para petani itu karena masalah tingginya pajak, maka dapat diartikan kebijakan pemerintah dalam masalah pajak tidak benar. Seperti disampaikan oleh Residen Madiun, “apabila persoalan pajak merupakan sebab yang sebenarnya bagi pemberontakan, maka kekuasaan kami (Belanda)

\footnotetext{
6 Ibid.

7 Sartono Kartodirdjo. Protest Movements in Rural Java: A Study of Agrarian Unrest in the Nineteenth and early Twentienth Centuries. Kuala Lumpur: Oxford University Press, 1978; Onghokham, "Pulung Affair: Pemberontakan Pajak di Desa Patik Beberapa Aspek Politik Desa di Madium pada Abad Ke-19”, Majalah Ilmu-ilmu Sastra Indonesia. Januari 1977, Jilid VII, No.1, 1-23.

8 Lihat misalnya proses verbal Mohammad Idris (No.22) 28 Mei 1886 dan proses verbal Tjajoet Ba Habiba dan Aserin Ba Atma (No.652) 9 April 1885 dalam Besluit No.1, 21 Agustus 1886, Arsip Nasional Republik Indonesia $(A N R I)$.
} 
menyerupai tiang di atas gurun pasir. ${ }^{9}$ Pernyataan Residen itu mendapat dukungan dari Kepala Dinas Pegawai Dalam Negeri (Directeur van Binnenlandsch Bestuur) yang menyatakan bahwa alasan tingginya pajak yang disampaikan para pemberontak adalah tidak benar dan merupakan alasan yang tidak berdasar. Masalah pajak dikemukakan oleh para pemberontak dalam rangka untuk mencari dukungan bagi pimpinan mereka. ${ }^{10}$

Demikian pula dalam peristiwa perlawanan petani di Ciomas, isu yang mencuat sebelum dan selama terjadinya aksi perlawanan adalah tingginya tuntutan pajak. Namun tuan tanah menyangkalnya dengan mengalihkan persoalan itu kepada masalah "perang suci" alias "perang fi sabilillah". Pada peristiwa aksi perlawanan petani di desa Patik, masalah beratnya beban pajak cukup terbukti. Namun para pengusaha Belanda yang mendukung Tuan Tanah Ciomas berusaha meyakinkan publik (masyarakat Belanda) bahwa peristiwa yang terjadi di Ciomas adalah dampak dari kebangkitan Islam di Sukabumi setahun sebelumnya, yang kurang mendapat perhatian pemerintah waktu itu. Peristiwa itulah yang kemudian mendorong munculnya gerakan radikal atau aksi kolektif yang disertai tindak kekerasan, seperti yang terjadi pada bulan Februari dan Mei 1886 di Ciomas itu.

Dalam proses verbal pada dasarnya cukup jelas ditunjukkan bahwa penyebab utama munculnya aksi kolektif yang disertai tindak kekerasan, adalah masalah ekonomi. Para peserta aksi mengaku bahwa tindakan itu dilakukan dengan penuh kesadaran yang cukup rasional. Mereka melihat aksi kolektif melawan para pembuat keputusan (pemerintah dan tuan tanah) merupakan salah satu alternatif yang paling rasional untuk mengubah nasib mereka (kesejahteraan mereka), yang berada di bawah garis subsistensi.

Memang harus diakui pula bahwa ada pula aksi perlawanan yang secara jelas menggunakan ide-ide keagaman, misalnya perlawanan rakyat Aceh dalam "Perang Belanda di Aceh". Namun konteks perlawanan Aceh berlainan dengan aksi-aksi kolektif yang disebutkan sebelumnya. Aceh atau Kesultanan Aceh Darussalam waktu itu, masih merupakan negara merdeka dan berdaulat. Jadi, perlawanan yang mereka lakukan bukanlah satu pemberontakan, melainkan salah satu upaya untuk mempertahankan kemerdekaan dan kedaulatan terhadap politik pasifikasi pemerintah Hindia Belanda.

Dalam perang Belanda di Aceh, yang dimulai sejak tahun 1873, lalu berkobar lebih dari 40 tahun, telah beredar banyak sekali hikayat perang yang dinamakan Hikayat Perang Sabil (HPS). Salah satu bagian dari HPS yang beredar itu, terjemahannya berbunyi sebagai berikut.

Waktu kafir menduduki negeri

Semua kita wajib berperang

Jangan berdiam bersunyi diri

\footnotetext{
${ }_{9}$ Onghokham, loc.cit., 7.

${ }^{10}$ Ibid., 8.
} 
Di dalam negeri bersenang-senang

Di waktu itu hukum fardhu 'ain

Harus yakin seperti sembahyang

Wajib berjalan cukup waktu

Kalau begitu dosa hai abang

Tak sempurna sembahyang puasa

Jika tak mara ke medan perang

Fakir miskin, kecil, dan besar

Tua, muda, pria, dan perempuan

Yang sanggup melawan kafir

Walaupun dia budaknya orang

Hukum fardhu 'ain di pundak kita

Meski tak sempat lunaskan hutang

Wajib harta disumbangkan

Kepada siapa yang mau berperang. ${ }^{11}$

Gema HPS yang dikutip di atas terbukti efektif untuk mengajak penduduk Aceh bertempur melawan Belanda. Hal ini antara lain terlihat dari jumlah korban pada pertempuran 11 Mei 1904 di Penosan, telah gugur 95 perempuan dan kanak-kanak. Kemudian di Tupeng pada 18 Mei 1904 telah gugur 51 perempuan dan kanak-kanak. Lalu pada 24 Juni 1904 di Kute Reh juga telah gugur 248 orang perempuan dan kanakkanak; dan di Lengat Baru pada 24 Juni 1904 telah gugur pula 316 orang perempuan dan kanak-kanak. ${ }^{12}$ Meskipun tidak begitu jelas apakah gema HPS itu sampai pula ke daerah atau tidak, namun gema perang Aceh itu sendiri sebagai perang sabilillah sampai pula ke daerah Priangan. Salah satu buktinya, di daerah Cicalengka, Bandung telah muncul gerakan untuk menghimpun berbagai jenis tanaman guna membantu orang-orang Aceh yang sedang berperang. ${ }^{13}$

Seperti dikatakan oleh Teuku Ibrahim Alfian, kepercayaan akan mendapat kebahagiaan setelah gugur dalam pertempuran melawan Belanda yang disebut oleh orang Aceh sebagai orang kaphé, tidak hanya dianut rakyat yang beragama Islam di Aceh, Palembang, dan pulau Jawa, tetapi juga diyakini oleh rakyat Indonesia yang beragama Hindu di pulau Bali. ${ }^{14}$ Besarnya pengaruh agama dalam kehidupan, terutama ide perang sabilillah memang membuat para pejabat kolonial Belanda ektra hati-hati, terutama yang berada di daerah yang pengaruh Islamnya cukup kuat. Hal ini antara lain tercermin dalama laporan Residen Priangan, Oosthout tahun 1907. Dalam laporannya

\footnotetext{
${ }^{11}$ Teuku Ibrahim Alfian, Wajah Aceh Dalam Lintasan Sejarah. Banda Aceh: Pusat Dokumentasi dan Informasi Aceh, 1999, 171.

${ }^{12}$ Ibid. h. 172.

${ }^{13}$ Mohammad Iskandar, Para Pengemban Amanah: Pergulatan Pemikiran Kiai dan Ulama di Jawa Barat. Yogyakarta: Mata Bangsa, 2001, 56.

${ }^{14}$ Ibid.
} 
itu ia mengatakan bahwa orang-orang Sunda lebih bersemangat dan lebih teguh dalam mempraktikan ajaran Islam ketimbang orang Jawa. Oleh karena itu meminta kepada Gubernur Jenderal agar tidak mengizinkan orang-orang Arab melakukan perjalanan ke daerah Priangan. ${ }^{15}$

Di pulau Jawa memang tidak ada lagi perang besar seperti di Aceh setelah berakhirnya perang Diponegoro (Perang Jawa) tahun 1830, yang dalam perekrutan pengikutnya juga menggunakan ide-ide keagamaan, perang sabil. ${ }^{16} \mathrm{Akan}$ tetapi tidak adanya perang besar tidak dapat diartikan bahwa rakyat di Jawa berhenti melawan penguasa kolonial Belanda. Perlawanan rakyat atau petani justru bermunculan walaupun dalam skala kecil, tapi cukup memusingkan pemerintah kolonial waktu itu.

Perlawanan rakyat atau petani semakin marak, terutama sejak pemerintah kolonial Hindia Belanda melakukan ekploitasi ekonomi secara besar-besaran melalui cultuurstelsel. Masuknya modal pemerintah yang disusul oleh modal swasta Barat ke daerah pedesaan, tidak saja sekedar menghadirkan perusahaan-perusahaan besar, tetapi juga budayanya. Oleh karena itu dampaknya pun bukan hanya pada bidang ekonomi, melainkan juga pada bidang budaya.

Secara ekonomi, para kapitalis memang mampu meningkatkan ekspor dari daerah koloni, walaupun dalam meningkatkan kesejahteraan penduduk pribumi, masih menjadi bahan perdebatan di kalangan para Indonesianis. Terlepas dari masalah kontroversi itu, yang pasti tingkat kesejahteraan penduduk pribumi pada akhir abad ke-19 dan awal abad ke-20 berada di bawah garis subsistensi.

Sementara secara budaya, kapitalisme juga ambil bagian dalam menghancurkan beberapa institusi dan tradisi desa yang semula sering menjadi tumpuan masyarakat. Lembaga gotong royong misalnya, secara perlahan tersisihkan oleh lembaga komersial. Sejalan dengan itu, desa yang sebelumnya tertutup berubah menjadi terbuka. Dengan hancurnya sebagian institusi desa, serta semakin terbukanya desa, maka kewajiban membayar pajak atau kerja wajib lainnya dirasakan oleh para petani desa lebih menghimpun dibandingkan dengan masa-masa sebelumnya. Tentu saja tingkat "kerusakan" itu di tiap daerah tidak selalu sama, tergantung dari struktur masyarakat serta para agennya. Oleh karena itu pula gerakan-gerakan sosial, termasuk di dalamnya aksi kolektif yang disertai dengan tindak kekerasan, mempunyai ciri-ciri yang bervariasi pula.

Sartono Kartodirdjo mengelompokan gerakan pemberontakan itu dalam empat kelompok, sesuai dengan isu-isu serta penyebab yang menjadi pendorong terjadinya pemberontakan tersebut. Keempat kelompok atau kategori itu ialah: (1) gerakan antipemerasan, (2) gerakan mesianistis, (3) gerakan revivalisme dan sektarian,

\footnotetext{
${ }^{15}$ Memorie van Overgave G. Oosthout, 4 November 1907, Algemeene Rijksarchief(ARA), Den Haag. 9.

${ }^{16}$ Saleh A. Djamhari, Strategi Menjinakkan Dipenogoro: Stelsel Benteng 1827-1830. Jakarta: Komunitas Bambu, 2003, 43.
} 
dan (4) gerakan Sarekat Islam (SI) lokal. ${ }^{17}$ Dari keempat kategori itu, hampir semua gerakan menggunakan ide-ide keagamaan, seperti ide perang suci atau sabilillah, termasuk penggunaan tarekat, dalam masa perekruitmen pesertanya, maupun selama pemberontakan itu terjadi. Misalnya dalam pemberontakan petani di tanah partikelir Ciomas tahun 1886, yang dikategorikan sebagai gerakan antipemerasan, pihak tuan tanah menuduh fanatisme keagamaan (Islam) sebagai bensinnya. ${ }^{18}$ Demikian pula dalam pemberontakan Achmad Ngisa yang terjadi pada tahun 1871, yang mengaku dirinya sebagai Ratu Adil atau Erucakra, yang dikategorikan sebagai gerakan mesianistis, juga dipergunakan ide perang suci dan penggunaan tarekat. ${ }^{19}$ Barangkali yang agak berbeda sifatnya adalah gerakan revival dan sektarian. Gerakan ini tidak dapat sepenuhnya dikatakan sebagai perlawanan terhadap dominasi Barat, melainkan lebih kepada perlawanan menghadapi tradisi agama yang dominan, misalnya terhadap Islam, seperti terlihat dalam gerakan agama Jawa atau Sunda. ${ }^{20}$

\section{ISLAM FOBI DAN POLITIK ISLAM PENGUASA KOLONIAL}

Seperti telah disinggung di atas, sikap Islam fobi nampak jelas dalam menyikapi peristiwa Cimareme dengan memunculkan kasus SI Afdeling-B. Sikap Islam fobi pada penguasa kolonial sebenarnya bukan hal yang baru. ${ }^{21}$ Jauh sebelum pemerintahan Hindia Belanda berdiri, tepatnya pada masa pemerintahan Vereenigde Oost Indische Compagne (VOC) atau Kompeni, sikap Islam fobi itu sudah kelihatan. Hal ini tidak terlepas dari budaya Barat yang berkembang waktu itu, termasuk di dalamnya isu Perang Salib. Apalagi dalam kenyataannya, pesaing utama Belanda (Barat) dalam perdagangan di kepulauan Nusantara datang dari para pedagang dan penguasa Islam. Sejak awal abad ke-18, yang dihadapi Kompeni bukan hanya penguasa pribumi, tetapi juga perlawanan rakyat atau petani, yang nota bene digerakkan oleh ulama-ulama Islam. Pada tahun 1710 misalnya, pemerintah Kompeni menerima laporan bahwa di daerah Jampang, Sukabumi terjadi aksi kolektif petani setempat yang menolak semua peraturan yang telah ditetapkan Kompeni yang dinilainya menyengsarakan rakyat. Sekitar 1000 orang petani di bawah pimpinan seorang ulama telah melakukan perlawanan. ${ }^{22}$ Tiga tahun kemudian muncul

\footnotetext{
${ }^{17}$ Lihat Sartono Kartodirdjo. Protest Movements in Rural Java. Institute of Southeast Asian Studies - Oxford University Press. 1978.

${ }^{18}$ Ibid., 29.

19 Ibid.,77.

${ }^{20}$ Ibid. 116.

${ }^{21}$ Lihat misalnya Lihat surat Hollen kepada Gubernur Jenderal Hindia Belanda 20 Agustus 1873 No. 126 dalam Verbalen 3 Juni 1874 No.31, ANRI. ; lihat juga anomim (X), "Koning" Otto: Een Banierdrager. S'Gravenhage: M. van der Beek. 1888.

${ }^{22}$ Dr, F.de Haan. Priangan: De Preanger Regentscappenonder Het Nederlandsch Bestuur tot 1811. Bataviaasch Genootschap van Kunsten en Weteschappen. 199, 470.
} 
gerakan yang dipimpin Dermakusuma yang hendak membunuh para bupati Priangan selatan. Dalam rekruitmen pengikutnya itu, dilaporkan bahwa Dermakusuma mendapat bantuan dari dua orang ulama. ${ }^{23}$ Oleh karena banyaknya kiai, ulama atau seorang haji yang terlibat dalam gerakan perlawanan itu, maka penguasa Kompeni mempunyai dugaan bahwa kunci perlawanan atau dalang pemberontakan itu adalah para kiai atau para haji itulah. Atas dasar dugaan itulah maka Kompeni berupaya memotong penyebaran ide-ide perang sabil itu dengan cara melakukan pengawasan terhadap arus balik para jemaah haji dari tanah suci Mekkah. Para haji yang dinilai cukup membahayakan atau dinilai berpotensi menimbulkan kesulitan bagi VOC, diupayakan untuk ditahan di Batavia, atau diasingkan ke tempat lain, jauh dari daerah asalnya.

Selain itu, maraknya perlawanan rakyat, juga dijadikan dasar pertimbangan oleh pemerintah kolonial dalam menjalankan kebijakan Islamnya, seperti memisahkan Islam sebagai agama (ibadah) dan Islam sebagai politik. Pemerintah kolonial, termasuk komunitas Belanda di Hindia Belanda, selalu mewaspadai setiap perkembangan di dunia Islam dengan penuh curiga. Bertambahnya jumlah mesjid, pesantren atau jemaah haji ditengarai sebagai kebangkitan Islam yang membahayakan. Demikian pula meningkatnya peserta pada pengajian-pengajian di mesjid-mesjid atau meningkatnya peserta tarekat, dipandang sebagai akan munculnya perang suci atau perang salib baru yang harus segera dicegah. ${ }^{24}$ Sebagai contoh pada tahun 1885 dilaporkan bahwa di daerah Sukabumi telah terjadi peningkatan jumlah santri di mesjid-mesjid dan pengajian-pengajian. Dalam laporan itu sama sekali tidak disebutkan mengapa jumlah peserta pengajian atau jumlah jemaah di mesjid meningkat demikian tinggi. Padahal jika dikaji secara seksama, dalam bulan-bulan tertentu yang terkait dengan bulan Saban (Rewah) atau Ramadhan (Puasa), umumnya jumlah pesertanya memang meningkat secara drastis. ${ }^{25}$

Sewaktu pada tahun 1886 terjadi aksi perlawanan petani di tanah partikelir Ciomas, Bogor yang memakan korban tidak kurang dari 50 orang meninggal dunia, disusul dua tahun kemudian (1888) terjadi lagi aksi perlawanan petani di Cilegon Banten, tidak sedikit dari komunitas Belanda di Hindia yang menyalahkan pemerintah. Mereka menganggap pemerintah Hindia Belanda lalai dan tidak mau menindaklanjuti laporan-laporan tentang perkembangan Islam di Sukabumi tahun 1885. Mereka yakin kejadian di kedua tempat itu mempunyai kaitan erat dengan kebangkitan Islam di wilayah Sukabumi. ${ }^{26}$ Bahkan administratur tanah partikelir Ciomas secara jelas menyebutkan bahwa penghulu kepala

\footnotetext{
${ }^{23}$ Ibid.

${ }^{24}$ Ibid. dan lihat juga E. de Waal, Onze Indische Financien, Nieuwe reeks aanteekeningen. Vol.I s'Gravenhage. 1876.

${ }^{25}$ Mohammad Iskandar, “Aksi Kolektif Petani Ciomas Tahun 1886 Dampak Politis Bagi Pemerintahan Hindia Belanda" (Disertasi tidak diterbitkan pada Program Studi Ilmu Sejarah Fakultas Ilmu Pengetahuan Budaya, Universitas Indonesia, 2007), 28 - 129.

${ }^{26}$ Ibid.; dan X, “Koning" Otto een branierdrager. S'Gravenhage: M. Van der Beek. 1888.
} 
Afdeling Bogor ikut terlibat dalam menghasut petani Ciomas untuk melawan pemilik sah tanah partikelir tersebut.

Dengan banyaknya ulama yang terlibat dalam perlawanan itu bertitel haji, maka pemerintah Hindia Belanda menerbitkan satu kebijakan "kehajian" yang tidak begitu populer di kalangan penduduk pribumi. Peraturan tersebut tertuang dalam Staatsblad tahun 1859 No.42. Dalam peraturan itu, khususnya fasal 5 disebutkan bahwa barang siapa yang kembali dari Mekah setelah selesai menunaikan ibadah haji, harus datang menghadap kepada Bupati atau yang menjadi gantinya memerintah di wilayah tempat kediaman orang itu. Di muka saksi, Bupati atau gantinya akan memeriksa serta menanyai orang itu, akan mengetahui benarkan dia telah pergi ke tanah suci. Jika ternyata benar, maka kepada orang itu akan diserahkan sehelai surat keterangan yang ditanda tangani oleh pihak yang memeriksa dan saksi-saksi, serta pula oleh orang itu sendiri. Bagi orang yang lulus, berhak memakai pakaian yang menggunakan simbol atau ciri-ciri kehajian seperti baju putih, sorban dan peci putih. Tapi jika tidak lulus, maka mereka dilarang menggunakan pakaian atau atribut kehajian. Bagi yang melanggar akan didensa mulai dari f.25 sampai f.100 (sebagai catatan waktu itu harga sepasang kerbau untuk membajak sawah harganya f.150). ${ }^{27}$ Meskipun peraturan itu cukup membingungkan dan mendapat kritikan keras dari berbagai pihak, termasuk dari para birokrasi pribumi, namun pemerintah tetap melaksanakannya. Walaupun demikian, karena sesuatu sebab, akhirnya peraturan itu dicabut kembali. ${ }^{28}$

Kebijakan seperti itu menunjukkan bahwa pengetahuan tentang Islam pada umumnya orang Belanda dan khususnya para petinggi pemerintah Hindia Belanda, jelas tidak memadai. Kondisi seperti itu yang disertai pula oleh stereo tipe terhadap Islam yang sudah berkembang lama di Eropa, membuat pemerintah Kolonial Belanda berkesimpulan bahwa radikalisme para petani itu disebabkan oleh ajaran Islam. Umumnya orang Belanda waktu itu memandang haji sebagai sosok yang kurang baik, yang hidup dari riba dan memeras bangsa sendiri. Mereka membeci haji yang dinilainya gila agama yang setiap waktu bersiap hendak merobohkan kekuasaan bangsa Eropa. ${ }^{29}$ Dengan kata lain Islam merupakan ancaman yang cukup serius yang secepatnya harus ditangani. Karena, jika tidak ditangani, bukan suatu hal mustahil kesulitan yang ditimbulkannya tidak dapat diselesaikan, bukan saja di tingkat lokal, tetapi juga di tingkat yang lebih luas; bahkan tidak mustahil akan berkembang semakin besar.

Salah satu lembaga yang dicurigai sebagai tempat pendidikan dan pelatihan

\footnotetext{
${ }^{27}$ Lihat Staatsblad voor Nederlandshe Indië Tahun 1859 No.42.

${ }^{28}$ Pangeran Aria Achmad Djajadiningrat. Kenang-kenangan. Kolff-Buning-Balai Pustaka. 1936.

${ }^{29}$ P.A. Achmad Djajadiningrat. Kenang-kenangan Pangeran Aria Achmad Djajadiningrat. Terjemahan Balai Pustaka, Kolff-Buning - Balai Pustaka. 1936, 228.
} 
orang-orang radikal adalah lembaga pesantren. ${ }^{30}$ Dalam bahasa yang lebih halus, para pejabat pemerintah menyebut lembaga pesantren dengan para kiai dan ulamanya sebagai faktor yang menghalangi modernisasi dan pembangunan. Para kiai dan ulamanya dikatakan hanya dapat mengajarkan ajaran yang meningkatkan sikap fanatis buta yang berujung kepada munculnya sikap radikal yang anti pemerintah. ${ }^{31}$ Sikap Islam phobia itu kemudian tercermin pula dengan diluncurkannya peraturan tahun 1905 (yang dikenal dengan nama ordonansi guru). Dalam peraturan itu disebutkan bahwa setiap orang yang hendak menyelenggarakan pendidikan Islam, harus meminta izin secara tertulis, dan juga harus menyebutkan apa yang hendak diajarkan serta jumlah para santrinya. ${ }^{32}$ Untuk mengawasi penerapan peraturan itu, pemerintah membentuk satu tim pengawas. Di setiap wilayah, ketua tim dipegang oleh bupati atau patih dengan penghulu sebagai salah satu anggotanya. Tentu saja banyak protes diajukan kepada pihak pemerintah yang dianggap telah melanggar ketentuannya sendiri, yaitu netral terhadap agama. ${ }^{33}$

Protes-protes itu pun akhirnya hanya membuahkan hasil yang tidak begitu memuaskan. Peraturan 1905 dicabut dan digantikan dengan peraturan tahun 1925. Dalam peraturan yang lebih baru ini, memang tidak ada lagi keharusan melaporkan jumlah santri dan masalah izin tertulis, namun tidak berarti para kiai dan para ustadz terbebas dari kewajiban membuat laporan. Berdasarkan peraturan baru itu, mereka masih tetap diwajibkan memberikan laporan tentang kegiatan pengajarannya kepada tim pengawas. ${ }^{34}$

Salah satu ajaran yang sering dianggap menjadi biangkeladi meningkatnyaa radikalisme di kalangan masyarakat Islam, khususnya para santri adalah ajaran tarekat. Oleh karena itu seringkali para pejabat pemerintah menilai tarekat sebagai ajaran sesat yang membahayakan yang perlu mendapat pengawasan dan kalau perlu dilarang diajarkan. Jauh sebelum ordonansi guru terbit, tepatnya pada 5 September 1886, K.F. Holle mengirimkan sebuah laporan kepada Gubernur Jenderal Hindia Belanda, bahwa di daerah Priangan Barat telah berkembang tarekat Naqsabandiah yang sangat membahayakan, yang disebutnya sebagai "kebangkitan Naqsabandiyah yang membahayakan". Namun ia tidak memperinci faktor-faktor atau ciri-ciri yang dijadikan tolok ukur untuk menunjukkan kesesatan kedua tarekat itu. Selanjutnya ia meminta agar pemerintah segera menanganinya secara serius.

Laporan yang hampir sama juga disampaikan oleh Residen Priangan pada tahun

\footnotetext{
${ }^{30}$ Salah satu karya otobiografi yang mengungkapkan tentang kecurigaan pemerintah terhadap lembaga pesantren adalah karya bupati Serang, Banten. Lihat Djajadiningrat, P.A.A. Achmad. Kenang-kenangan. Batavia. 1936.

${ }^{31}$ Achmad Djajdiningrat. Op.cit.

32 Staatsblad voor Nederlandsch-Indie. 1905, No.550.

33 Balantentara Islam. No. 1, 27 Desember 1924.

${ }^{34}$ Staatsblad voor Nederlandsch-Indië. 1925, No.219.
} 
1892. Dalam laporannya itu ia menyebutkan bahwa di kabupaten Cianjur berkembang tarekat Naqsabandiyah dan Qadiriyah. Kedua tarekat itu ternyata telah menjerat hati masyarakat setempat, sehingga banyak masyarakat yang melupakan kewajiban-kewajiban agama. ${ }^{35}$ Seperti halnya Holle, Residen Priangan juga tidak menjelaskan kewajibankewajiban agama Islam seperti apa yang dilupakan oleh para pengikut tarekat tersebut.

Demikian pula Adviseur voor Inlandsche Zaken, R.A. Kern dalam laporannya tahun 1925 mengutarakan rasa kekhawatirannya dengan perkembangan tarekat Naqsabandiyah di daerah Cianjur. Dasar kekhawatiran itu karena di daerah kabupaten Cianjur banyak sekali pesantren dengan kiai-kiainya yang kharismatis. Kemungkinan besar karena dia menduga bahwa pesatren-pesatren itu akan menjadi ladang yang subur bagi persemaian tarekat yang dinilai sering menjadi semacam premium mobile bagi pemberontakan para petani. Padahal dari laporan yang dibuat oleh penghulu Tasikmalaya atas pesanan penguasa kolonial, kecurigaan semacam itu tidak terbukti. Dari beberapa ratus pesantren yang ada di Priangan, hanya beberapa pesantren saja yang mengajarkan tarekat. ${ }^{36}$

Peristiwa Cimareme itu sendiri ternyata berdampak cukup besar pada kehidupan pesantren-pesantren, tidak hanya di wilayah Garut saja, melainkan juga di wilayah lainnya, terutama di lingkungan keresidenan Priangan. Banyak pesantren di wilayah itu yang kehilangan kiai atau gurunya karena dipenjara dengan tuduhan terlibat dalam SI afdeling B. Tidak sedikit pula kader kiai yang semula akan disekolahkan ke "AlAzhar" di kota Kairo-Mesir, terpaksa membatalkan rencananya karena dicekal oleh pemerintah setempat. Sebagai contoh, Yusuf Tojiri dari pesantren Cipari-Garut yang terpaksa harus mengubur impiannya menjadi santri atau mahasiswa Al Azhar karena ayahnya, Kiai Haji Ajengan Harmaen dipenjara karena dinilai telah membantu gerakan SI afdeling B, sementara dirinya harus tetap tinggal di Garut sebagai saksi. ${ }^{37}$ Demikian pula nasib pesantren Nangkapait, Cilame-Garut, yang terpaksa kehilangan gurunya, yaitu Kiai Haji Ajengan Muhammad Adra'i, yang disebut-sebut sebagai ketua SI afdeling B. ${ }^{38}$ Ia terpaksa harus pergi meninggalkan Garut dan bersembunyi di Malaka, Malaysia. Sementara pesantren Genteng, terpaksa menghentikan kegiatan ajar mengajarnya karena panutannya yaitu Kiai Haji Ajengan Ahmad Sanusi ditangkap dengan tuduhan telah membantu menyembunyikan Kiai Adra'i yang menjadi buronan polisi. ${ }^{39}$

\footnotetext{
${ }_{35}$ Mohammad Iskandar. Para Pengemban Amanah: Pergulatan Pemikiran Para Kiai dan Ulama di Jawa Barat 1900-1950. Yogyakarta: Mata Bangsa. 2001, 59.

${ }^{36}$ Lihat arsip Residensi Priangan No.75, Arsip Nasional Republik Indonesia (ANRI).

37 Hiroko Horikoshi. Kiai dan Perubahan Sosial. Jakarta: P3M. 1987, 83-84.

38 Laporan singkat wedana dan asisten wedana Sukabumi tgl. 10 Oktober 1927 dan surat Residen Priangan Barat tgl. 15 Desember 1927 No.50/E Rahasia, salinan dalam Mailr. Geheim No. 679x/28, ARA.

${ }^{39}$ Mohammad Iskandar, “Agama dan Radikalisme: Suatu Sketsa Sejarah” paper pada Seminar Internasional Agama dan Radikalisme. Depok, Fakultas Ilmu Pengetahuan Budaya-Universitas Indonesia, 14 Desember 2005.
} 
Peristiwa Cimareme secara langsung telah merugikan nama baik SI. Menurut Pemerintah Hindia Belanda, dari bukti-bukti yang ditemukan di rumah Haji Hassan dan rumahlainnya yang dicurigai, serta dari pengakuan para saksi dan terdakwa, menunjukkan bahwa radikalisme yang diperlihatkan keluarga Haji Hasan dan pengikutnya antara lain disebabkan oleh pengaruh ajaran sesat yang dibawa oleh SI Afdeling-B. ${ }^{40}$ Pemerintah yakin bahwa kelompok yang disebut SI Afdeling-B merupakan bagian yang tidak terpisahkan dari SI yang dipimpin oleh Cokroaminoto. Kelompok ini dipersiapkan untuk melakukan pemberontakan terhadap pemerintah Hindia Belanda. Mereka akan membunuh semua orang-orang Eropa dan Cina yang dinilai telah menyengsarakan rakyat pribumi. Serta merta pihak SI menolak dengan tegas semua tuduhan itu. Cokroaminoto selaku pimpinan CSI mengatakan bahwa tidak tahu-menahu tentang eksistensi SI Afdeling B. Apalagi ikut terlibat dengan segala aktivitasnya dalam mempersiapkan suatu pemberontakan.

Meskipun demikian, pihak pemerintah tetap mencurigai SI afdeling B sebagai sayap radikal SI yang rahasia sifatnya. Apalagi dalam tahun itu, peristiwa yang nyaris serupa terjadi pula di Toli-Toli, Sulawesi. Bertolak dari kedua peristiwa itu pemerintah Hindia Belanda merasa perlu untuk "membekukan" sementara keanggotaan Cokroaminoto pada lembaga Volksraad.

\section{PENUTUP}

Sejak menjelang akhir abad ke-20, penguasa Republik Indonesia, seperti halnya Amerika Serikat, Inggris, dan Australia, disibukkan oleh isu-isu teroris. Meskipun tidak secara inklusif menyatakan Islam berada dibalik maraknya aksi teroris itu, namun secara tidak langsung tuduhan itu selalu diarahkan ke kelompok Islam. Misalnya dalam menanggapi peristiwa serangan terhadap World Trading Centre di New York, Presiden Amerika Serikat George W. Bush mengatakan bahwa kampanye melawan teroris tidak dimaksudkan untuk perang melawan Islam. Akan tetapi dalam praktiknya, Islam yang disalahkan, yang dapat dilihat misalnya dalam tindakan diskriminatif dalam bentuk penyisiran nama-nama yang berbau atau identik Islam. ${ }^{41}$

Demikian pula kecurigaan penguasa di Republik Indonesia dalam hal-hal tertentu tidak jauh berbeda dengan Bush. Seringkali kaum musliman dituding sebagai pihak yang selalu memaksakan ingin mengubah negara atau dasar Negara, Pancasila dengan hukum Islam. Apalagi setelah munculnya organisasi-organisasi transnasional seperti Hizbut Tahrir Indonesia yang secara terang-terangan ingin menegakkan khilafah Islamiah. Pada masa Orde Baru, banyak organisasi atau kelompok Islam yang dinilai fanatis dan keras,

\footnotetext{
${ }^{40}$ Kern, Op.cit. ; Kaoem Moeda. No.21, 31 Januari 1920.; Nama lain dari Si afdeling-B adalah: "Gunaperlaya", "Bargo" dan " Adhidarma, Lihat Verklaring Wedana Banjar 14 Juli 1919 dalam Mailrapporten Geheim No. 510X/19, Algemeene Rijksarschief (ARA), Den Haag, Netherland.; dan Kaoem Moeda No.27, 9 Februari 1920.

${ }^{41}$ Karen Amstrong. Perang Suci: Dari Perang Salib hingga Perang Teluk. Jakarta: Serambi. 2001.
} 
ditumpas atau dijerat hukum dengan tuduhan gerakan komando jihad, teroris atau aliran sesat. Kebijakan pemerintah RI yang seringkali mirip dengan kebijakan pemerintah kolonial Hindia Belanda, seringkali meremehkan penyebab utama yang mendorong terjadinya gerakan-gerakan radikal yang dikatagorikannya sebagai perongrong stabilitas nasional. Ingatan kolektif penguasa terhadap peristiwa Darul Islam (DI) cukup kuat, tapi tidak lupa bahwa Pan Islamisme di masa kolonial tidak laku di kalangan umumnya kaum muslimin pribumi; dan juga lupa bahwa di BPUPKI kelompok Islam tidak memaksakan kehendaknya menjadikan Indonesia sebagai negara Islam. Dari beberapa kejadian yang kemudian dikaji secara ilmiah, seperti peristiwa Tanjung Priok (1984) dan peristiwa Warsidi (1989), ternyata apa yang dituduhkan oleh pihak pemerintah Orde Baru pada dasarnya tidak terbukti, atau masih perlu diteliti ulang.

Suatu peristiwa pada dasarnya tidak akan muncul begitu saja seperti permainan sulap atau sihir. Semuanya melalui proses, apalagi menyangkut budaya atau agama yang ideologi dalam praktik-praktik keseharian. Keterlibatan seseorang dalam satu aksi kolektif atau gerakan politik, tentu bukan tanpa dasar atau pemikiran. Masalah untung rugi, sekecil apa pun akan diperhitungkan dalam peran sertanya itu. Apa pun agamanya, seorang atau kelompok orang yang merasa tidak nyaman dalam satu struktur, maka ia akan mengubahnya agar struktur itu menjadi nyaman bagi kehidupannya. Seperti dikatakan oleh Anthony Giddens, aktivitas sosial manusia, seperti halnya benda-benda alam yang berkembang biak sendiri, saling terkait satu sama lain. ${ }^{42}$

Mungkin saja masalah agama Islam yang mendorongnya ikut secara aktif dalam satu aksi kolektif yang disertai tindak kekerasan. Namun fakta semacam itu belum cukup kuat dijadikan satu dalil untuk menggeneralisir semua aksi kolektif yang radikal disebabkan oleh ajaran Islam. Sama halnya dengan masalah kemiskinan itu yang menjadi faktor pendorong terjadinya pemberontakan di satu daerah, tidak secara otomatis dapat dijadikan untuk menggeneralisir bahwa kemiskinan dapat menyulut terjadinya pemberontakan. Seperti dikatakan oleh James C. Scott bahwa masalah pemberontakan adalah misteri. Jika kemiskinan merupakan penyebab pemberontakan, maka semua Dunia Ketiga sudah terbakar oleh pemberontakan. Jika kita analogikan pernyataan Scott ini dengan fenomena Islam dalam arti Islam sebagai penyebab terjadinya gerakan radikal atau pemberontakan, maka seharusnya sebagian besar Asia Tenggara dan Timur Tengah telah terbakar oleh pemberontakan. ${ }^{43}$

\footnotetext{
${ }^{42}$ Anthony Giddens. Teori Strukturasi: Dasar-dasar Pembentukan Struktur Sosial Masyarakat. Yogyakarta: Pustaka Pelajar. 2010, hal. 3. Lihat juga Charles Tilly, From Mobilization to Revolution, Addison-Wesley Publishing Company, 1978 dan Bert Klandermans, Protes Dalam Kajian Psikologi Sosial. Yogyakarta: Pustaka Pelajar. 2005.

${ }^{43}$ James C. Scott. Moral Economi Petani: Pergolakan dan Subsistensi di Asia Tenggara. Terjemahan oleh: Hasan Basari. Jakarta: LP3ES. 1981.
} 


\section{DAFTAR ACUAN}

\section{ARSIP}

Algemeen Rijksarschief (ARA), Den Haag.

Verbalen 3 Juni 1874 No.31.

Arsip Nasional Republik Indonesia. (ANRI), Jakarta

Arsip Residensi Priangan No.75

Memorie van Overgave G. Oosthout, 4 November 1907

Koninklijk Instituut voor Taal, Land-en Volkenkunde (KITLV), Leiden

Koleksi R.A. Kern No. 343

\section{SUMBER TERCETAK}

Staatsblad voor Nederlandsch-Indië. 1905, No.550

Staatsblad voor Nederlandsch-Indië. 1925, No.219.

\section{BUKU, ARTIKEL, DAN SKRIPSI}

Alfian, Teuku Ibrahim. Wajah Aceh Dalam Lintasan Sejarah. Banda Aceh: Pusat Dokumentasi dan Informasi Aceh. 1999

Armstrong, Karen. Perang Suci: Dari Perang Salib hingga Perang Teluk. Terjemahan oleh: Hikmat Darmawan, Jakarta: Serambi. 2001.

Djajadiningrat, P.A.A. Achmad. Kenang-kenangan. Batavia. 1936.

Djamhari, Saleh A. Strategi Menjinakkan Dipenogoro: Stelsel Benteng 1827-1830. Jakarta: Komunitas Bambu. 2003.

Ensering, Else. "De ontdekking van de Afdeeling B van de Sarekat Islam al seen case study in de locale geschiedenis van de Preanger Regentschappen" (Skripsi doctoral Universitas Amsterdam, Amsterdam. 1982)

Hiroko Horikoshi. Kiai dan Perubahan Sosial, Jakarta: P3M. 1987

Iskandar, Mohammad. Para Pengemban Amanah: Pergulatan Pemikiran Para Kiai dan Ulama di Jawa Barat 1900-1950. Yogyakarta: Mata Bangsa. 2001.

Kartodirdjo, Sartono. Protest Movements in Rural Java. Institute of Southeast Asian Studies - Oxford University Press. 1978.

Protest Movements in Rural Java: A Study of Agrarian Unrest in the Nineteenth and early Twentienth Centuries. Kuala Lumpur: Oxford University Press. 1978

Ratu Adil. Jakarta: Sinar Harapan. 1984

Klandermans, Bert. Protes Dalam Kajian Psikologi Sosial. Yogyakarta: Pustaka Pelajar. 2005.

Tilly, Charles. From Mobilization to Revolution. Addison-Wesley Publishing Company. 1978.

Waal, E. de. Onze Indische Financien, Nieuwe reeks aanteekeningen. Vol.I s'Gravenhage. 1876.

X. "Koning" Otto een branierdrager. S'Gravenhage: M. Van der Beek. 1888.

\section{KORAN}

Balantentara Islam. No. 1, 27 Desember 1924

Kaoem Moeda No.27, 9 Februari 1920 